\title{
Approval of the patient care line with rare diseases, Brazil's Portaria 199 and its National Policy. What does that mean? What changes?
}

We all know that rare diseases are neglected in Brazil! Some of us know that rare diseases are not well known! However, we all need to know that this may be different now!

The concept of rare disease (RD), according to the World Health Organization (WHO), is a disease that affects up to 65 people in every 100 thousand individuals, that means 1.3 for each 2 thousand people. In Brazil, it is estimated that 13 million people have rare diseases (RDs), most of them reaching children, more than half of whom are diagnosed late. RDs are usually chronic, progressive, debilitating, unhealing, with decreasing loss of autonomy by the patient, who faces along with his family prejudices and lack of hope in healing and in therapies.

Actually, we know that these diseases exist since Antiquity. They were the focus of dozens of informal and formal reports over the history of mankind. However, for some years now important facts have "emerged": the advent of molecular biology, the lack of adequate diagnosis, the prosecution of high-cost drugs (for example: enzyme therapies produced by genetically engineering) and lack of specialized treatment for such pathologies.

The possibility of resolution of these questions became a reality when several regions of Brazil, through highly qualified professionals-geneticists, cried for guidelines to treat the patients. In 2012 a working group was established to elaborate a National Policy for attention to RDs in the SUS, composed by the representatives of the Ministry of Health (MS), by specialists in RDs and by associations linked with RDs. Among the participants, both indicated by the Ministry of Health and by associations, there were some professionals-geneticist members of the Brazilian Society of Medical Genetics (SBGM). The process of elaboration took place in several stages, including public enquiry, and the text of the policy was published in early 2014 (Portaria GM/MS No. 199 of 01/30/2014).

\section{THE ORDINANCE No 199, OF JANUARY 30, 2014}

Establishes the National Policy for total care for persons with rare diseases, approves the guidelines for gtter care for persons with rare diseases under extent of the Unified Health System (SUS) and establishes financial cost incentives.

For the purpose of organization and service's accreditation, the policy was divided into "rare genetic origin" and "rare nongenetic". This way, two axes of rare diseases were listed:

1) composed by rare diseases of genetic origin: a - Congenital anomalies or of late manifestation, b - Intellectual deficiency, c Inborn errors of metabolism; the axis of congenital anomalies includes any functional or structural anomaly of fetal development, due to a factor originated before birth, whether genetic, environmental or unknown, even when the malformations were not apparent in the newborn and only manifested later (PAHO, 1984).

2) and the second formed by RD of non-genetic origin: a- Infectious, b - Inflammatory, c - Autoimmune, and d - Other Rare Non-Genetic Diseases.

Adding up to all this, and not least important, are included care to family members and patients with RD should ensure:

a) structure of care in an integrated and coordinated manner at all levels, since the prevention, welcoming, diagnosis, treatment (based on clinical protocols and therapeutic guidelines - PCDTs), support until resolution, following up and rehabilitation;

b) access to diagnostic and therapeutic resources;

c) access to information and care;

d) genetic counseling $(\mathrm{GA})$, when indicated.

The implementation of the policy will depend on the State and Municipal Health Secretariats, the SUS agents.

With the advances in health (new vaccines, basic sanitation, etc.), deaths from diseases that are defined as "no or less" genetic, are 
declining and diseases with genetic "influences" are increasingly increasing and are responsible for a greater number of death by specific diseases in a part of the population.

It is now imperative to all health teams in Brazil and in the world to know the RDs. Only by knowing the line of care of these diseases and with valid protocols by competent teams, of which Ceará is setting an example for Brazil and for the world with the creation of the Ceará's Rede Raras, we can finally diagnose, rehabilitate and treat these diseases in the right and universal way.

\section{REFERÊNCIAS}

Brazilian Society of Medical Genetics [Internet]. [place unknown]: SBGM; [2017] - [cited 2017 Aug 10]. Available from: http://sbgm.org.br/

Ministério da Saúde (Brasil). Portaria nº 199, de 30 de janeiro de 2014. Institui a Política Nacional de Atenção Integral às Pessoas com Doenças Raras, aprova as Diretrizes para Atenção Integral às Pessoas com Doenças Raras no âmbito do Sistema Único de Saúde (SUS) e institui incentivos financeiros de custeio. Diário Oficial da União. 2014 fev 12; seção 1 (30): 44-54.

Nussbaum RL, McInnes RR, Willard HF. Thompson \& Thompson Medical Genetics. 7. ed. [place unknown]: Guanabara Koogan; 2008.

OMIM Online Mendelian Inheritance in Man [Internet]. [place unknown]: Johns Hopkins University; [2017] - [cited 2017 Aug 10]. Available from: https://www.omim.org/

Pan American Health Organization [Internet]. [place unknown]: PAHO; [1984] - [cited 2017 Aug 10]. Available from: http://iris.paho.org/xmlui/ World Health Organization [Internet]. [place unknown]: WHO; [cited 2017 Aug 10]. Available from: http://www.who.int/en/
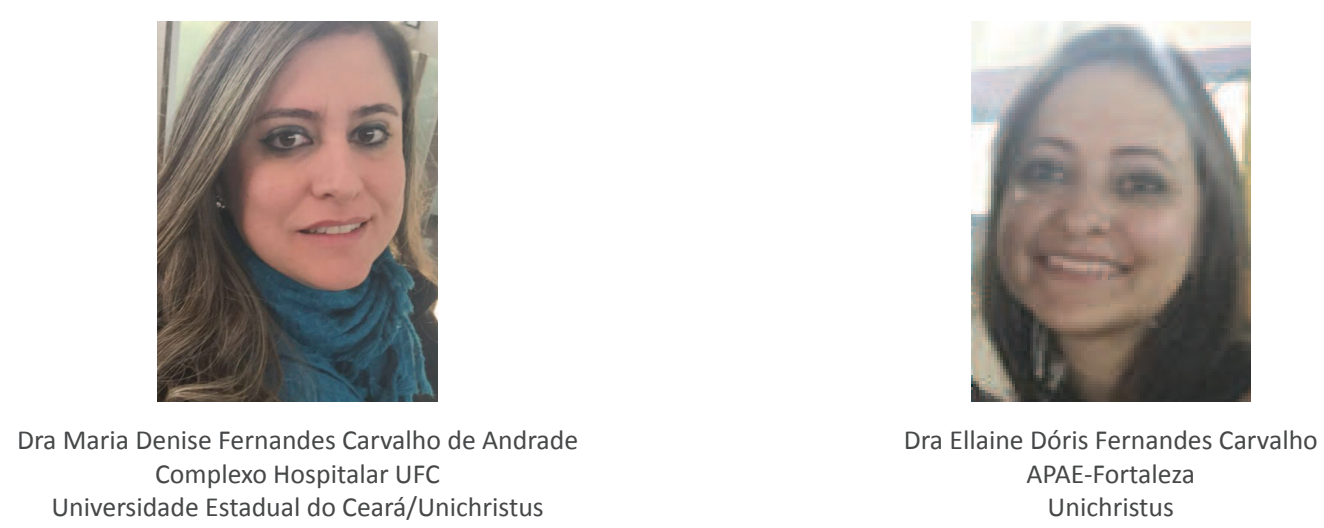

Como citar:

Andrade MD, Carvalho ED. Approval of the patient care line with rare diseases, Brazil's Portaria 199 and its National Policy. What does that mean? What changes? Rev Med UFC. 2017 mai-ago;57(2):6-7. 